JKEP

Vol 4, No 1, Mei 2019

ISSN: 2354-6042 (Print)

ISSN : 2354-6050 (Online)

\title{
Peran Pendamping Minum Obat (PMO) dalam Keteraturan Konsumsi Obat Klien TBC
}

\author{
Wartonah, Eska Riyanti, Nelly Yardes \\ Jurusan Keperawatan Poltekkes Kemenkes Jakarta III \\ Email:Wartonah03@yahoo.co.id
}

\author{
Artikel history \\ Dikirim, Jan $18^{\text {th }}, 2019$ \\ Ditinjau, Feb $18^{\text {th }}, 2019$ \\ Diterima, Maret 24 2019
}

\begin{abstract}
Tuberculosis is a contagious pulmonary infection and the biggest cause of death after cardiovascular disease and diabetes mellitus. The non-compliance of patients with pulmonary $T B$ in taking medication causes the patient's recovery rate to be low, high mortality rates and recurrence increases and has an impact on bacterial resistance to some anti-tuberculosis drugs and is very difficult to cure. This study aims to determine the factors most associated with adherence to taking anti-pulmonary TB drugs in the Cipayung District Health Center East Jakarta area. The research method used is Cross sectional. The sample used was 60 respondents who matched the inclusion criteria. Data collection was done using questionnaires and data analysis using Chi-Square test. Data analysis showed that there was a significantly relationship between role of PMO with OR 2,6 ( $p$ value $=0,000)$ with adherenceto taking antipulmonary TB drugs. The results showed that TB clients 2.6 times would regularly take TB medication if the PMO reminded them of taking medication
\end{abstract}

Keywords: Companion; Pulmonary TB; compliance with taking medication

\begin{abstract}
ABSTRAK
Tuberkulosis merupakan penyakit infeksi paru menular dan penyebab kematian terbesar setelah kardiovaskuler dan diabetes militus. Ketidakpatuhan pasien TB Paru dalam minum obat menyebabkan angka kesembuhann pasien rendah, angka kematian yang tinggi dan kekambuhan meningkat serta berdampak pada resisten kuman terhadap beberapa obat anti tuberculosis dan sangat sulit disembuhan. Penelitian ini bertujuan untuk mengetahui factor yang paling berhubungan dengan kepatuhan minum obat anti TB Paru di wilayah Puskesmas Kecamatan Cipayung Jakarta Timur. metode penelitian yang digunakan adalah Crossectional. Sampel yang digunakan sebanyak 60 orang responden yang sesuai kriteria inklusi. Pengumpulan data dilakukan dengan menggunakan kuesioner dan analisa data menggunakan uji ChiSquare. Analisis data menunjukkan bahwa terdapat hubungan yang bermakna antara variabel peran PMO dengan OR 2,6 ( $\mathrm{p}=0,000)$ dengan keteraturan minum obat TB Paru. Hasil penelitian disimpulkan bahwa klien TB Paru akan 2,6 kali lebih teratur minum obat bila PMO mengingatkan untuk minum obat.
\end{abstract}

Kata Kunci: Pendamping; TB Paru; kepatuhan minum obat 


\section{PENDAHULUAN}

Tuberculosis (TB) Paru merupakan penyakit infeksi yang disebabkan oleh mycobacterium tuberculosis dengan gejala yang sangat bervariasi. Tuberculosis paru merupakan masalah kesehatan masyarakat di seluruh dunia, terutama di Negara-negara sedang berkembang. Data Organisasi Kesehatan Dunia (WHO) pada 2014, menempatkan Indonesia sebagai negara dengan penderita TB Paru terbanyak kedua setelah India. Di Indonesia mencapai 1 juta dengan jumlah kematian mencapai 110 ribu per kasus tiap tahunnya, sedangkan di tahun 2016 menyatakan Indonesia masih menempati rangking kedua dengan jumlah kasus TB Paru terbanyak di dunia dan menjadi penyebab kematian nomor empat setelah penyakit kardiovaskuler. Di DKI Jakarta tahun 2015 tercatat 10.844 penyakit TB Paru sedangkan Jakarta Timur jumlah kasus TB Paru yang ditemukan dari bulan Januari sampai dengan Juni 2017 terdapat 6.315 pasien dan merupakan yang terbanyak di DKI Jakarta dibandingkan wilayah lain.

Terkait prevalensi penderita tuberkulosis di Indonesia menunjukan bahwa angka keberhasilan pengobatan di Indonesia masih rendah. Untuk mencapai kesembuhan dibutuhkan keteraturan minum obat bagi setiap penderita.
Pengobatan dilakukan setiap hari dan jangka panjang, sehingga kepatuhan minum obat salah yang harus dipikirkan sejak awal pengobatan. Minum obat yang tidak rutin terbukti telah menyebabkan resistensi obat yang dapat menyebabkan kegagalan pengobatan. Berdasarkan hal tersebut, tentu perlu adanya pengaturan penggunaan obat sesuai tujuannya terutama obat seperti yang dikehendaki. Aturan minum obat sangat berpengaruh pada kepatuhan penderita (Nirmala, 2003). Pengobatan yang tidak benar akan mengakibatkan resistensi kuman TB terhadap obat yang diberikan. Hal ini akan menimbulkan kesulitan yang amat besar, penderita akan menularkan kumanya kepada orang lain dan biaya pengobatan menjadi meningkat dan waktu yang lama untuk pengobatan (Aditama, 1994). Penderita yang patuh berobat adalah yang menyelesaikan pengobatan secara teratur dan lengkap tanpa terputus, selama minimal 6 bulan dampai dengan 9 bulan (Depkes RI, 2000). Penderita dikatakan lalai dalam pengobatan jika tidak datang lebih dari 3 hari sampai 2 bulan dari tanggal perjanjian dan dikatakan droup out jika lebih dari 2 bulan berturut-turut tidak datang berobat setelah dikunjungi petugas kesehatan (Depkes RI, 2000).

Menurut Niven (2002) bahwa faktor-faktor yang mempengaruhi kepatuhan diantaranya sikap atau motivasi individu ingin sembuh, 
keyakinan, dukungan sosial, dukungan dari petugas kesehatan, selain itu faktor lain adalah peran PMO, kolaborasi petugas kesehatan dengan keluarga yang ditunjuk untuk mendampingi ketika penderita minum obat, juga faktor yang perlu dievaluasi untuk menentukan tingkat kepatukan dan keberhasilannya (Purwanta, 2005).

Pengawas minum obat (PMO) adalah orang yang bertugas mengawasi secara langsung terhadap penderita tuberculosis paru pada saat minum obat setiap harinya dengan menggunakan panduan obat jangka pendek (Depkes RI,2000). Menurut Ditjen PPM dan PLP (1997), tujuan utama diadakannya PMO pada penderita TB paru diantaranya menjamin ketekunan dan keteraturan pengobatan sesuai jadwal yang telah disepakati pada awal pengobatan, menghindari penderita dari putus berobat sebelum waktunya, mengurangi kemungkinan kegagalan pengobatan dan kekebalan terhadap obat anti tuberkulosis (OAT).

Sebaiknya PMO adalah petugas kesehatan, bila tidak ada petugas kesehatan dapat berasal dari kader kesehatan, guru, anggota PKK atau tokoh masyarakat lainnya atau anggota keluarga (Nuraini, 2005). Tugas PMO menurut Nuraini (2003) diantaranya mengetahui tanda-tanda tersangka TB Paru, mengawasi penderita minum obat setiap hari, mengambil obat bagi penderita seminggu sekali, mengingatkan penderita untuk periksa ulang dahak, memberikan penyuluhan pada penderita dan keluarga, memberitahukan adanya suspek pada keluarga penderita dan merujuk kalau ada efek samping obat.

\section{METODE}

Metode penelitian yang digunakan adalah Krosseksional atau potong lintang, dimana variabel-variabel yang termasuk faktor risiko dan variabel-variabel yang termasuk efek diobservasi sekaligus pada waktu yang sama. Penelitian ini umumnya dilakukan pada hubungan penyebab dan kejadian penyakit yang relatif pendek. Hal ini lebih efisien untuk merumuskan hipotesis baru namun lebih lemah dalam pengujian hipotesis kasual (Hidayat, 2011). Variabel yang akan dianalisis adalah pengetahuan, sikap penderita, umur tingkat penghasilan, tingkat pendidikan, jarak fasilitas kesehatan, sikap petugas kesehatan dan peran pendamping Minum Obat serta tingkat kepatuhan minum obat anti TB. Sebelum penelitian ini dimulai, dilakukan pengajuan ethical approval dan mendapat ijin meneliti dari pemerintah Kota Administrasi Jakarta Timur. Penelitian dilakukan di wilayah Kecamatan Cipayung Jakarta Timur. Populasi yang dijadikan 
objek penelitian adalah seluruh pasien TB paru dengan jumlah jumlah sampel 60 orang yang diambil dengan metode simple random sampling. Penelitian ini akan dilakukan pada bulan Juli - November 2018.
Pengunpulan data penelitian menggunakan lembar kuesioner yag terdiri dari kuesioner karakteristik klien dan data terkait pengobatan TB Paru. Data diolah dan dianlisis menggunakan metoda analisis Chi-Square untuk mengetahui nilai Oods Ratio dan tingkat kemaknaan.

\section{HASIL DAN PEMBAHASAN}

Hasil analisis data penelitian menunjukkan karakteristik responden sebagi berikut;

Tabel1

Distribusi Karakteristik Responden $(\mathrm{n}=60)$

\begin{tabular}{lcc}
\hline \multicolumn{1}{c}{ Variabel } & \multicolumn{2}{c}{ Frekuensi } \\
\cline { 2 - 3 } & $\mathrm{N}$ & $\%$ \\
\hline Tingkat pendidikan & 51 & 85.0 \\
$\quad$ Rendah & 9 & 15.0 \\
Tinggi & & \\
Pekerjaan & 27 & 45 \\
$\quad$ Tidak Bekerja & 33 & 55 \\
$\quad$ Bekerja & & \\
Umur & 39 & 65 \\
$\quad \geq 36$ tahun & 21 & 35 \\
$\quad<36$ tahun & & \\
\hline Penghasilan & 31 & 51.7 \\
$\quad<1.000 .000$ & 29 & 48.3 \\
$\quad \geq 1.000 .000$ & & \\
Peran PMO & 20 & 33.3 \\
Tdk Mengingatkan & 40 & 66.7 \\
Mengingatkan & & \\
Jarak rumah- PKM & 26 & 43.3 \\
$\quad>2$ km & 34 & 56.7 \\
$<\quad 2$ km & & \\
Sikap Petugas & 27 & 45 \\
Tidak setuju & 33 & 55 \\
Setuju & & \\
\hline
\end{tabular}

Tabel 2 
Hubungan Determinan dengan Kepatuhan Minum obat TB di Puskesmas Kecamatan Cipayung Jakarta Timur, Tahun 2018

\begin{tabular}{|c|c|c|c|c|c|c|c|}
\hline \multirow{3}{*}{ Variabel } & \multirow[t]{3}{*}{ Kategori } & \multicolumn{4}{|c|}{ Kepatuhan } & \multirow[t]{3}{*}{ OR } & \multirow{3}{*}{$\begin{array}{c}\mathrm{p} \\
\text { value }\end{array}$} \\
\hline & & \multicolumn{2}{|c|}{ Tdk patuh } & \multicolumn{2}{|c|}{ Patuh } & & \\
\hline & & $\mathrm{N}$ & $\%$ & $\mathrm{~N}$ & $\%$ & & \\
\hline \multirow[t]{2}{*}{ Umur } & $>36$ thn & 3 & 7.7 & 36 & 92.3 & 0.020 & 0.040 \\
\hline & $<=36$ thn & 6 & 28.6 & 15 & 71.4 & & \\
\hline \multirow[t]{2}{*}{ Pendidikan } & Tinggi Rendah & 8 & 17.7 & 43 & 8 & 0.148 & 0.593 \\
\hline & & 1 & 11.1 & 84.3 & 88.9 & & \\
\hline \multirow[t]{2}{*}{ Pekerjaan } & TdkBekerja & 3 & 11.1 & 24 & 88.9 & 0.052 & 0.349 \\
\hline & Bekerja & 6 & 18.8 & 27 & 81.8 & & \\
\hline \multirow[t]{2}{*}{ Penhasiln } & $<1000.000$ & 4 & 12.9 & 27 & 87.1 & 0.071 & 0.456 \\
\hline & $>1000.000$ & 5 & 17.2 & 24 & 82.8 & & \\
\hline Sikap & Tdk Setuju & 7 & 25.9 & 20 & 74.1 & 0.251 & 0.037 \\
\hline Petugas & Setuju & 2 & 6.1 & 31 & 93.9 & & \\
\hline \multirow[t]{2}{*}{ PMO } & Tdk Ingatkan & 8 & 40.0 & 12 & 60.0 & 2.647 & 0.000 \\
\hline & Mengingatkan & 1 & 2.5 & 39 & 97.5 & & \\
\hline \multirow[t]{2}{*}{ Jarak Rumah } & $>2 \mathrm{~km}$ & 7 & 26.9 & 19 & 73.1 & 0.295 & 0.029 \\
\hline & $<=2 \mathrm{~km}$ & 2 & 5.9 & 32 & 94.1 & & \\
\hline
\end{tabular}

Hasil penelitian menunjukkan bahwa mayoritas responden dengan umur lebih dari 36 tahun yang memiliki kepatuhan minum obat anti tuberculosis sejumlah $92.7 \%$ dengan $\mathrm{p}=0.040(<0,05)$ dengan demikian dapat disimpulkan bahwa terdapat hubungan bermakna antara umur dengan kepatuhan minum obat anti tuberculosis. Hal ini dapat dihubungkan bahwa semakin dewasa umur seseorang maka semakin matang pola berfikirnya. Menurut Bart orang yang berusia lanjut cenderung mengikuti anjuran dokter, lebih memiliki tanggung jawab, lebih tertib, lebih teliti, lebih bermoral dan lebih berbakti dari pada usia muda. Dari segi biologis perilaku manusia adalah suatu kegiatan atau aktifitas yang dilakukan oleh manusia itu sendiri, biasanya sejalan dengan bertambahnya umur secara biologis mempengaruhi manusia untuk mengambil tindakan. Hasil penelitian ini tidak sejalan dengan hasil penelitian yang dilakukan Kondoy (2014) bahwa umur tidak berhubungan dengan kepatuhan minum obat. 
Hasil penelitian menunjukkan bahwa responden dengan sikap petugas yang setuju dan yang memiliki kepatuhan 93,9 $\%$. Berdasarkan hasil uji chi square di dapatkan hasil p $0.037(<0,05)$ dengan demikian dapat disimpulkan bahwa terdapat hubungan bermakna antara sikap petugas dengan kepatuhan minum obat anti tuberculosis. Hal ini sejalan dengan hasil penelitian yang dilakukan oleh Dewi dan Perdana dalam Mubarak, 2007, bahwa sikap petugas kesehatan berhubungan dengan kepatuhan minum obat TB Paru. Sikap petugas kesehatan yang baik dapat berfungsi sebagai tempat konseling kesehatan. Selain itu juga dapat digunakan sebagai tempat bertanya oleh individu, keluarga, kelompok dan masyarakat untuk memecahkan berbagai masalah dalam bidang kesehatan yang dihadapi (Mubarak, 2007). Hasil penelitian ini juga sejalan dengan Niven (2002) mengatakan bahwa faktor yang mempengaruhi kepatuhan salah satunya dukungan dari petugas kesehatan. Dukungan petugas terutama berguna saat pasien menghadapi bahwa perilaku sehat yang baru tersebut merupakan hal yang penting.
Hasil penelitian menunjukkan bahwa responden dengan PMO yang memiliki kepatuhan minum obat 97,5 \% . Berdasarkan hasil uji chi square di dapatkan hasil $\mathrm{p}=0.000(<0,05)$ dengan demikian dapat disimpulkan bahwa terdapat hubungan bermakna antara PMO dengan kepatuhan minum obat anti tuberculosis. Hasil penelitian tidak sejalan dengan hasil penelitian yang dilakukan Ahmad Hudan bahwa pendamping minum obat tidak berhungan dengan ketaatan minum obat anti TB Paru. Namun sejalan dengan hasil penelitian Dewi dan Amelda yang menyatakan bahwa terdapat hubungan yang bermakna antara PMO dengan kepatuhan minum obat. Keluarga sangat berperan dalam memotivasi atau mendukung pasien TB Paru untuk dapat berobat secara teratur. Adanya PMO dapat berpengaruh terhadap ketaatan pasien dalam minum obat secara teratur sampai pasien dinyatakan sembuh oleh petugas kesehatan Nuraini (2003).

Hasil penelitian menunjukkan bahwa responden dengan jarak pelayanan kesehatan $<=2 \mathrm{~km}$ memiliki kepatuhan 94,1\%.Berdasarkan hasil uji chi square di dapatkan hasil p $0.029(<0,05)$ dengan demikian dapat disimpulkan bahwa 
terdapat hubungan bermakna antara jarak peyanan kesehatan dengan kepatuhan minum obat anti tuberculosis.Hasil penelitian ini sejalan dengan hasil penelitian yang dilakukan oleh Ahmad Hudan bahwa jarak rumah dengan pelayanan kesehatan berhubungan dengan ketaatan minum obat anti TB Paru, hal ini disebabkan karena jarak yang dekat memudahkan responden untuk mengambil obat, biaya murah dan tidak memerlukan waktu yang lama. Notoatmojo menjelaskan bahwa semakin jauh jarak dari rumah pasien ke tempat pelayanan kesehatan dan sulitnya transportasi maka, akan berhubungan dengan keteraturan berobat. Selain itu persepsi sehat dan sakit,dikatakan bahwa setiap seseorang yang sakit akan mencari pengobatan ketempat yang dianggap dapat

\section{DAFTAR RUJUKAN}

Amin, Z. d. 2006. Tuberkulosis Paru, Buku Ajar Ilmu Penyakit Dalam. Jakarta: FKUI.

Dahlan ,MS(2010). Besar Sampel dan cara pengambilan Sampel Dalam Penelitian Kedokteran dan kesehatan, Jakarta Salemba Medika

Departemen Kesehatan Republik Indonesia.2011. Pedoman Nasional Penanggulangan Tuberkulosis. Edisi 2. Jakarta : Gerdunas. memberikan pengobatan sehingga bisa mencapai kesembuhan atas sakit yang dideritanya.

\section{SIMPULAN}

Hasil penelitian membuktikan bahwa peran PMO cukup berpengaruh dan signifikan terhadap keteraturan komsumsi obat TB Paru pada klien. Sehingga klien yang didampingi oleh PMO akan meningkatkan keteraturannya 2,6 kali dalam mengkonsumsi obat jika dibandingkan dengan yang tidak didampingi PMO. Untuk meningkatkan keteraturan berobat perlu tetap ditingkatkan kemampuan self efikasi klien dengan memberikan pengetahuan yang cukup dan mendorong motivasi serta dukungan keluarga selama menjalani tahap pengobatan dalam jangka waktu yang lama.

GendhisI D, YunieA, Mamat S. 2011. Hubungan antara Pengetahuan,Sikap Pasien dan Dukungan Keluarga Dengan Kepatuhan Minum Obat Pada Pasien TB Paru di Bkpm Pati.

Sylvia A,P. 2009. Patofisiologi Konsep Klinis Proses-ProsesPenyakit. Edisi 6. Jakarta : EGC.

RamadhaniA. 2010. Pengaruh Pelaksanaan Pengawas Menelan Obat ( PMO ) Terhadap Konversi 
BTA (+) Pada Pasien TB Paru di RSDK.

Pare, A L dkk. 2012. Hubungan antara Pekerjaan, PMO, Pelayanan Kesehatan, Dukungan Keluarga dan Diskriminasi dengan Perilaku Berobat Pasien TB Paru. Fakultas Kesehatan Masyarakat Universitas Hasanudin. Makassar.

Notoadmodjo, Soekidjo dkk. 2007. Promosi KesehatanTeoridan Aplikasi. Jakarta : PT. RinekaCipta.

Smet B . 1974. Psikologi Kesehatan. Jakarta : PT. Grasindo.. Hal 250-256

Niven N. 2002. Psikologi kesehatan pengantar untuk perawat dan profesional kesehatan lain. Jakarta : EGC

Nandangtisna. 2009. FaktorFaktor yang Berhubungan Dengan Tingkat Kepatuan Pasien Dalam Minum Obat Anti Hipertensi di Puskesmas Pamulang Kota Tangerang Selatan Propinsi Banten.

Badan Penelitian dan Pengembangan Kesehatan Kementerian Kesehatan RI. 2010. Riset Kesehatan Dasar.

Syafni M. 2010. Faktor-Faktor Yang Berhubungan Dengan Keteraturan Penderita TB Paru Dalam Minum $O A T$ di Puskesmas Kecamatan Johar Baru Jakarta Pusat.

NotoadmodjoS dkk. 2005. Pendidikan dan Perilaku Kesehatan. Jakarta : PT. Rineka Cipta.

Preti D. 2011. Faktor Yang BerpengaruhTerhadapKepatuahn Pengobatan( Berobatdan Minum
Obat ) Penderita Tuberkulosis Paru di 5 Puskesmas di Kota BOGOR.

World Health Organisation. 2006. Global Tuberculosis Control: surveillance, planning, financing. WHO report 2006. Geneva: World Health Organisation.

World Health Organisation. 2012. Global Tuberculosis Report. Geneva: World Health Organisation 